\title{
Biological Activity of the Labdane Diterpenes**
}

\author{
Meenakshi Singh ${ }^{1}$, Mahesh Pal ${ }^{2}$, and R. P. Sharma ${ }^{2, *}$ \\ ** CIMAP Publication No. 98-4] \\ ${ }^{1}$ Department of Chemistry, Isabella Thoburn College, Lucknow, India \\ 2 Phytochemical Technology Division, Central Institute of Medicinal and Aromatic Plants (CIMAP), Lucknow, India
}

Received: January 29, 1998; Revision accepted: August 29, 1998

\begin{abstract}
Biological activity of diterpenes of the labdane skeleton, isolated from the terrestrial plants and marine sources during the last ten years has been reviewed.
\end{abstract}

Key words: Labdane diterpenes, terrestrial plants, sponges, antibacterial, antifungal, anti-inflammatory activity.

\section{Introduction}

Although twenty thousand plant species are used in traditional medicines, most species have not been thoroughly examined chemically or pharmacologically. This review gives an account of the work done on the bioactive labdane diterpenes from plants and marine sources during the last ten years (1987-1997). The biological activity detected in labdane diterpenes from the natural sources has been discussed in relation to chemical structure under the respective titles.

\section{Antibacterial Activity}

Cistus incanus (Cistaceae), a native of the Mediterranean region is used in folk medicine for the treatment of several diseases. From the leaves of C.incanus, a series of labdane diterpenes were isolated (1). In vitro antibacterial testing was carried out using the disk diffusion method against Grampositive Staphylococcus aureus, S. epidermis and Gram-negative Pseudomonas aeruginosae, Enterobacter cloacae, Klebsiella pneumoniae and Escherichia coli. Netilmicin, ceftazidine, ceftriaxon and ampicillin were used as standard antibiotics for comparison. The isolated compounds were tested at a concentration of $100 \mu \mathrm{g} / \mathrm{ml}, 13$-episclareol (1), labdan-14-ene8,13-diol (2), 5R,8R,9R,10R-labdan-13(E)-ene-8a,15-diol (3) and $5 R, 8 R, 9 R, 10 R$-labdan-13(E)-en-8a-ol-15-yl acetate (4) were found to be more active than ampicillin on K.pneumoniae, S. aureus and P. aeruginosae.

Another series of labdane diterpenes was isolated from the methanolic extract of the leaves of Viburnum suspensum (Caprifoliaceae) (2). These labdanes were termed as gomojosides $\mathrm{A}-\mathrm{J}$ and differed only in the substitution pattern. Gomojoside B (5), C (6), E (7) and F (8) were found to exhibit

Planta Medica 65 (1999) 2-8

(c) Georg Thieme Verlag Stuttgart $\cdot$ New York

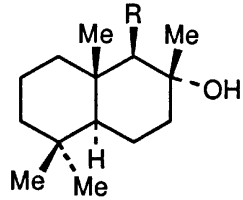

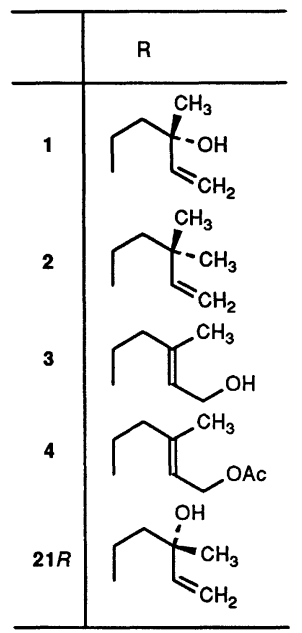

antibacterial activity at a concentration of $500 \mathrm{ppm}$ in nutritional agar medium against E.coli. Further chemical investigation of the polar fractions of Viburnum suspensum led to the isolation of new labdane diterpenes (3). The new labdane monoglycosides were termed as gomojosides $\mathrm{K}-\mathrm{O}(\mathbf{9 - 1 3})$. They differed among themselves and with the previously isolated gomojosides $\mathrm{A}-\mathrm{J}$ in the substitution pattern and in stereochemistry. All the new labdane gomojosides $\mathrm{K}-\mathrm{O}$ (913) with the desired structural nucleus exhibited potent antibacterial activity against Aeromonas salmonishida at a concentration of $100 \mathrm{ppm}$ in nutritional agar medium. Gomojosides M (11) was also found to be active against Bacillus subtilis.

From the bark of Juniperus procera (Cupressaceae) (4), abietanes exhibiting antibacterial activity were isolated and on further investigation two known labdane diterpenes, cryptotrienolic acid (14) and isocupressic acid were isolated. The diterpenes were tested against B. subtilis, S. aureus, Streptococcus durans, Enterococcus faecalis and Mycobacterium intra- 
<smiles>[R]C1CC2(C)C(CC/C(C)=C/COC)C(=C)CC([R7])C2(C)C1[Y4]</smiles>

\begin{tabular}{c|lllll}
\hline & $\mathrm{R}^{1}$ & $\mathrm{R}^{2}$ & $\mathrm{R}^{3}$ & $\mathrm{R}^{4}$ & \\
\hline $\mathbf{5}$ & $\mathrm{H}$ & $\mathrm{H}$ & $\mathrm{COOGlc}$ & $\mathrm{H}$ & \\
$\mathbf{6}$ & $\mathrm{H}$ & $\mathrm{H}$ & $\mathrm{CH}_{2} \mathrm{OGlc}$ & $\mathrm{H}$ & $\Delta^{13,14}$ \\
$\mathbf{7}$ & $\mathrm{H}$ & $\mathrm{H}$ & $\mathrm{CH}_{2} \mathrm{OGlc}$ & $\mathrm{OH}$ & $\Delta^{13,14}$ \\
$\mathbf{8}$ & $\mathrm{H}$ & $\mathrm{H}$ & $\mathrm{CH}_{2} \mathrm{OGlc}$ & $\mathrm{OH}$ & \\
$\mathbf{9}$ & $\mathrm{OH}$ & $\mathrm{OH}$ & $\mathrm{CH}_{2} \mathrm{OH}$ & $\mathrm{OH}$ & $\Delta^{13,14}$ \\
$\mathbf{1 0}$ & $\mathrm{H}$ & $\mathrm{H}$ & $\mathrm{CH}_{2} \mathrm{OH}$ & $\mathrm{OH}$ & \\
$\mathbf{1 1}$ & $\mathrm{H}$ & $\mathrm{OH}$ & $\mathrm{CH}_{2} \mathrm{OH}$ & $\mathrm{H}$ & $\Delta^{13,14}$ \\
$\mathbf{1 2}$ & $\mathrm{OH}$ & $\mathrm{H}$ & $\mathrm{CH}_{2} \mathrm{OH}$ & $\mathrm{H}$ & $\Delta^{13,14}$ \\
$\mathbf{1 3}$ & $\mathrm{H}$ & $\mathrm{OH}$ & $\mathrm{CH}_{3}$ & $\mathrm{OH}$ & $\Delta^{13,14}$ \\
\hline
\end{tabular}

cellular. Amikacin sulfate, streptomycin sulfate and isonicotinic acid hydrazide were used as positive standards while the solvent dimethyl sulphoxide was used as a negative control. Cryptotrienolic acid (14) was found to exhibit weak antibacterial activity whereas isocupressic acid was found to be inactive.

Premna oligotricha (Verbenaceae) is a shrub occurring widely in East Africa. The twigs are used as chewing sticks while the smoke formed by burning the plant is used to sterilise milk containers. These uses suggest the probable presence of antibacterial compounds. The crude ethanolic extract of P. oligotricha (5) showed antimicrobial activity against a wide range of Gram-positive bacteria. Some Gram-positive bacteria, for example, Streptococcus sp. are responsible for dental caries and Lactobacillus sp. are an important group of acid-forming bacteria which are also responsible for dental problems. Compound (14a) was found to be active against a number of Gram-positive bacteria and streptomycin was used as standard for comparison.

The oceans with their millions of species are a rich source of marine plants and animals. In recent years a number of potential therapeutic agents have been isolated from marine flora and fauna. Keeping this in view, from the methanolic extract of the frozen Thai sponge belonging to the genus Mycale, mycaperoxides A (15) and B (16) were isolated (6). The structure and stereochemistry was established with the help of 2D NMR. Mycaperoxides A (15) and B (16) both exhibited antibacterial activity by inhibiting the growth of Gram-positive bacteria B. subtilis and S. aureus. Besides this both the diterpenes exhibited antiviral activity $\left(\mathrm{IC}_{50} 0.25\right.$ $1.0 \mu \mathrm{g} / \mathrm{ml}$ ) against vesicular stomatitis and herpes simplex type- 1 virus.

During the search for biologically active sulfated sponge metabolites belonging to the sesterpenoid class, a sulfated sesterterpene hydroquinone halisulphate (17) was isolated from the dark brown sponge (Halichondriidae) and it inhibited the growth of $S$. aureus at a concentration of $5 \mu \mathrm{g} / \mathrm{disk}$ and B. subtilis at $50 \mu \mathrm{g} /$ disk in in vitro antimicrobial (7) assays.<smiles>[R7]C1([R7])C(C)=CCC2C(C)(C)CCCC21[R7]</smiles>

(n-

\section{Antifungal Activity}

A wide variety of synthetic and natural compounds has been found to inhibit the growth of pathogenic fungi and ensure successful treatment of most superficial fungal infections. There is still a need to search for safer drugs with low toxicity which can be administered parenterally or orally and reach the site of infection in effective concentrations.

From the seeds of Alpinia galanga (Zingiberaceae), some antifungal principles with a labdane nucleus, $(E)-8(17), 12-$ labadiene-15,16-dial (18), E-8 $\beta(17)$-epoxylabd-12-ene-15,16dial (19) and galanolactone (20) were isolated (8) and tested against various strains of Candida. Compounds 18 and 19 exhibited strong antifungal activity against Candida albicans, C. gurilliermondii, C. tropicalis and C. utilis. Galanolactone (20) also exhibited antifungal activity against the above strains of Candida, but was found to be less potent as compared to the compounds 18 and 19. Total synthesis of galanolactone (20) was carried out starting from a known cyanoketone (9).

Aframomum daniellii (Zingiberaceae) (10) growing as a perennial herb is valued for its roots which are used as a purgative. The seeds produce a hot taste on chewing. Extraction of the seeds with hexane yielded 8 $\beta, 17$-epoxy-12Elabdene-15,16-dial (19) along with 8(17),12E-labdadiene15,16-dial (18). A.danielli is a new source of antifungal compounds 18 and 19. 


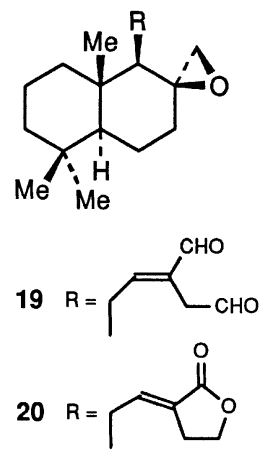

Sclareol (21) a labdane diterpene and a potent growth inhibitor of rust fungi is used commercially in the manufacture of ambergis perfume. The diterpene is not widely distributed, the most convenient source is from the leaves of Nicotiana glutinosa (Solanaceae) and flower heads of Salvia sclarea (11). Sclareol at a concentration of $100 \mu \mathrm{g} / \mathrm{ml}$ gave good control of rust fungi on french bean, broad bean and wheat, reducing infection to less than $10 \%$ of the control. Since the diterpene is not widely distributed, there has been a great interest to develop cell lines for accumulating this compound and also to purify the enzyme responsible for its formation from the biogenetic precursor.

Compounds isolated from the leaves of Cistus incanus (1) were tested for antifungal activity against C.albicans, Torulopsis glabrata and the infectious fungus Saccharomyces cerevisiae. $5 R, 8 R, 9 R, 10 R$-Labdane-13(E)-ene-8a,15-diol (3) was the only compound found to be active against the fungus $C$. albicans at a concentration of $1 \mu \mathrm{g} / \mathrm{ml}$.

Halisulfate (17) isolated from a dark brown sponge (7) (Halichondriidae) was found to inhibit the growth of C.albicans at a concentration of $5 \mu \mathrm{g} /$ disk.

\section{Anti-Inflammatory Activity}

Most commonly used anti-inflammatory agents are aspirin and non-steriodal anti-inflammatory drugs (NSAIDs). Extensive work has been carried out in the search for antiinflammatory agents of natural origin. The leaves of Cryptomeria japonica (Taxodiaceae), a Japanese plant, are used in traditional medicine for the treatment of eczema, swelling and injury by topical application. During the search for antiinflammatory constituents from C.japonica (12), the activity was found to be due to the compound cis-communic acid (22). The activity testing was done using the carrageenaninduced paw edema (CPE) method in rats. cis-Communic acid (22) was found to inhibit the histamine induced contraction in ileum isolated from guinea pig, as histamine is used in the CPE test. The acid was isolated as a colourless oil and was found to be less stable and was converted into another compound within a few hours at room temperature. The sodium salt of the acid obtained as a colourless powder was found to be rather stable. This is the first time that a compound having a labdane skeleton is reported to show anti-inflammatory activity.

\section{Antileishmanial Activity}

Very few chemotherapeutic synthetic agents such as the pentavalent antimonials, sodium antimony gluconate and antimony $\mathrm{N}$-methylglutamine, are used as antileishmanial agents but are toxic and expensive. Very few natural products are known as antiprotozoal and diospyrin is one of them. In the search for new leishmanicidal agents the neutral extract of the stem bark of Polyalthia macropoda (Annonaceae) was subjected to in vitro bioassay on cultures of Leishmania donovani, a visceral leishmaniasis agent (13). On the basis of the results obtained the conclusion was drawn that the diterpene (23) at a concentration of $0.25 \mathrm{mg} / \mathrm{ml}$ inhibits the parasites cell division to an extent of $15 \%$ complete inhibition, i.e., $100 \%$ of the parasite growth was observed at a concentration of $1.5 \mathrm{mg} / \mathrm{ml}$ with an $\mathrm{LD}_{50}$ of $0.75 \mathrm{mg} / \mathrm{ml}$.

\section{Cardiotonic Activity}

At present, many effective agents of synthetic and natural origin are available. Cardiac glycosides of natural origin have shown better responses as compared to synthetic drugs. The new structures discovered can be used by pharmaceutical chemists as models for the synthesis of structural analogs with improved activity. During the chemical screening of the root part of Melodinus monogynus (Apocyanaceae) it was found that the plant is rich in butenolides (14). A number of genins and their corresponding glycosides were isolated. One of the genins isolated was identified as medigenin (24). Medigenin (24) and medigenin acetate (25) both exhibited cardiotonic activity in isolated frog heart and isolated mammalian heart. Medigenin (24) increased the tone and force of contraction of the heart and the heart rate was decreased. Similar positive inotropic and negative chronotropic effects were observed on the isolated rabbit heart. The acetylated derivative (25) also increased the tone and force of myocardial contraction and decreased the heart rate and was more potent than medigenin.

\section{Cytotoxic Agents}

On screening the $\mathrm{CHCl}_{3}$ extract of the rhizomes of Hedychium coronarium (Zingiberaceae), it was found to inhibit the growth of Chinese hamster V-79 cells and sarcoma 180 ascites in mice (15). Detailed chemical analysis led to the isolation of a known (E)-labda-8(17),12-diene-15,16-dial (18) along with four new coronarins A-D (26-29). All the compounds exhibited cytotoxicity whereas coronarin A and B exhibited significant activity. The cytotoxicity of various compounds was assessed by determining $\mathrm{T} / \mathrm{C}$ (number of stained colonies of test group/those of control groups $) \times \mathrm{IC}_{50}$. Solutions of $10 \mu \mathrm{l}$ each of various concentrations $(1,3,10,30 \mu \mathrm{g} / \mathrm{ml})$ were added to the cultures of cloned Chinese hamster V-79 cells.

Several compounds have been isolated from the resin "ladano" obtained from the plant Cistus creticus (Cistaceae). Detailed phytochemical analysis led to the isolation of diterpenes from the resin (16). The diterpenes 3, 30, 31 with labdane nucleus along with other diterpenes were tested for cytotoxic activity using different cell lines: MOLT 3, a human cell $\mathrm{T}$ cell line originating from a patient with acute lymphoblastic leukemia (ALL); RAJI cells, a pre-B-cell line originating from a patient with Burkitt lymphoma; and $\mathrm{H} 9$ cells 


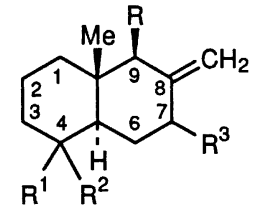

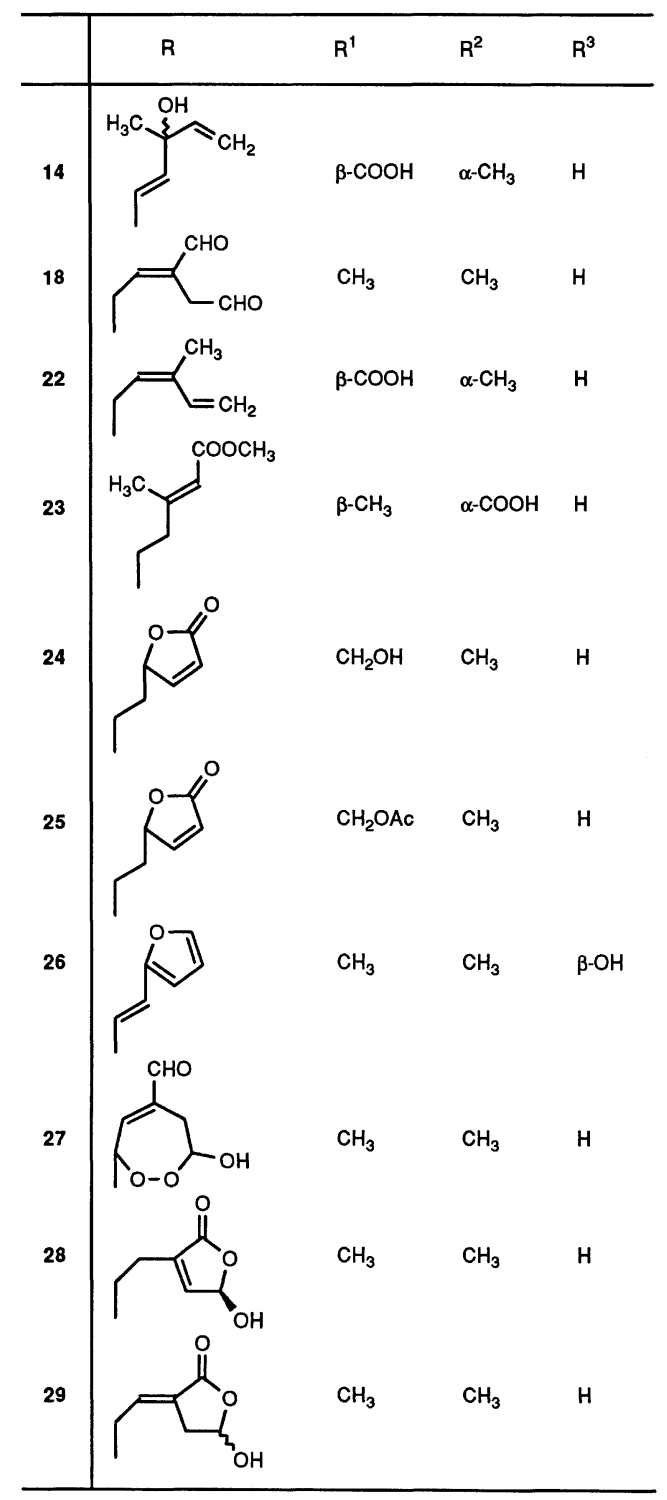

originating from a patient (ALL). All tests were carried out at three different concentrations $(15,7.5$ and $3.75 \mu \mathrm{g} / \mathrm{ml})$ and using methotrexate as a standard drug. After in vitro testing it was found that compounds $\mathbf{3}, \mathbf{3 0}, \mathbf{3 1}$ proved to be active against RAJI, MOLT 3 and $\mathrm{H} 9$ cell lines. The compounds were also found to be active against the murine leukemia P-388 (3PS) and KB cell lines.

Cell differentiation inducers may act as new types of antitumour agent and hence there is a need for naturally occurring substances which induce differentiation of leukemia cells. For screening of this activity an assay of inducing phagocytosis of polystyrene latex particles by mouse myeloid leukemia (MI) cells was used. Andrographis paniculata (Acan- thaceae) is widely used in the traditional system of medicine in India, South East Asia and China. The methanolic extract of the aerial parts of A. paniculata showed potent differentiation inducing activity on MI cells (17). It was found that all the diterpenoids isolated from $A$. paniculata have the same carbon skeleton as that of andrographolide (32), which is considered to be a common intermediate. The diterpenoids isolated were tested for cell differentiation inducing activity against MI cells. Monomeric compounds 32, 33, 34, 35, 37, 38, 39 showed potent activity whereas compound $\mathbf{3 6}$ showed moderate cell differentiation activity. Compounds 32, 33, 34 showed a phagocytic ratio of more than $30 \%$ at the concentration of $5 \times$ $10^{-6} \mathrm{M}$. Dimeric compounds 40, 41, 42 also showed potent activities and were found to be more active than the monomers. The dimer $\mathbf{4 3}$ showed no induction of phagocytosis but was found to be growth inhibitory. This might be due to cleavage of one of the two $\alpha, \beta$-unsaturated $\gamma$-lactones. The glucoside derivatives 44, 45, 46, 47 and 48 showed weak activities of pagocytosis induction and growth inhibition, although the acetyl derivative $\mathbf{4 8}$ was relatively potent. The conclusion drawn from the above result was that compounds with an $\alpha, \beta$-unsaturated $\gamma$-lactone having an exo-olefinic group or diene group conjugated with the lactone carbonyl are effective inducers of phagocytosis.

Mycaperoxides A (15) and B (16) isolated from the sponge Mycale sp. (6) showed significant cytotoxicity $\left(\mathrm{IC}_{50}=0.5-\right.$ $1.0 \mu \mathrm{g} / \mathrm{ml}$ ) against cell lines of P-388, A-549 and HT-29.

(E)-8 $3(17)$-Epoxylabd-12-ene-15,16-dial (19) and galanolactone $(\mathbf{2 0})$ exhibited mild cytotoxicity against $\mathrm{KB}$ cells $\left(\mathrm{ED}_{50}=\right.$ $38.5 \mu \mathrm{g} / \mathrm{ml}$ and $22.5 \mu \mathrm{g} / \mathrm{ml}$, respectively) (8).

\section{Inhibitors of Adenosine Transfer}

From the marine orange sponge Agelas mauritiana, two novel non-quaternary adenine derivatives of a bicyclic diterpene, agelasimine $A(\mathbf{4 9})$ and $B(\mathbf{5 0})$ both exhibiting a wide range of biological activities, were isolated (18). Cytotoxicity was exhibited by both compounds when tested against L-1210 mouse leukemia cells in vitro $\left[\mathrm{ED}_{50}=2-4 \mu \mathrm{g} / \mathrm{ml}\right]$. Their effect on the smooth muscle relaxation of rabbit gut and bovine coronary artery was studied and both caused relaxation in the tissue $\left[\mathrm{ED}_{50}=3-10 \mu \mathrm{m}\right]$. Nucleoside transport into rabbit erythrocytes ( $\mathrm{IC}_{50}=6-14 \mu \mathrm{m}$ ) was inhibited by agelasimine $\mathrm{A}$ (49) and $\mathrm{B}(\mathbf{5 0})$. Both the compounds acted as $\alpha$-adrenergic blockers and as $\mathrm{Ca}^{2+}$ channel antagonists.

\section{Inhibitors of Aldose Reductase}

Accumulation of sugar sorbitol formed from D-galactose by aldose reductase enzyme results in the appearance of cataract of the lens of eyes in galactosemic patients. Due to the increasing therapeutic demand new inhibitors of aldose reductase are needed. From the marine sponge Dysidea sp. (19) some metabolites inhibiting the activity of enzyme aldose reductase were isolated. The active principle isolated was dysideapalaunic acid (51) with a labdane unit. Total synthesis along with elucidation of the absolute stereochemistry of natural (+)dysideapalaunic acid (51) has been carried out (20). 


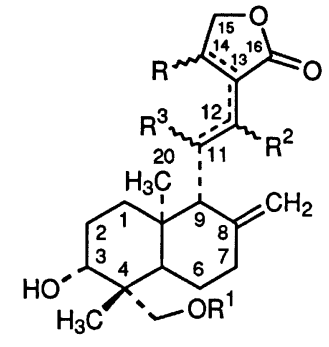

\begin{tabular}{|c|c|c|c|c|c|}
\hline & $\mathbf{R}$ & $R^{1}$ & $R^{2}$ & $\mathrm{R}^{3}$ & \\
\hline 32 & $\alpha-\mathrm{OH}$ & $H$ & $\mathrm{H}$ & $\mathrm{H}$ & $\Delta^{12,13}$ \\
\hline 33 & $\beta-\mathrm{OH}$ & $H$ & H & H & $\Delta^{12,13}$ \\
\hline 34 & $\mathrm{OH}$ & H & $\mathrm{H}$ & H & $\Delta^{12,13}$ \\
\hline 35 & $\mathrm{H}$ & H & $\mathrm{H}$ & H & $\Delta^{13,14}$ \\
\hline 36 & H & H & $\mathrm{OCH}_{3}(\alpha$ or $\beta)$ & H & \\
\hline 37 & H & H & $\mathrm{OCH}_{3}(\beta$ or $\alpha)$ & H & \\
\hline 38 & H & H & $\mathrm{OH}(\alpha$ or $\beta)$ & $\mathrm{H}$ & \\
\hline 39 & $\mathrm{H}$ & $\mathrm{H}$ & $\mathrm{H}$ & $\alpha-\mathrm{OH}$ & $\Delta^{13,14}$ \\
\hline $40-42$ & $\mathrm{H}$ & $H$ & & $H$ & $\Delta^{13,14}$ \\
\hline 43 & $H$ & $H$ & & H & $\Delta^{13,14}$ \\
\hline 44 & $\alpha-\mathrm{OH}$ & Glc & H & H & $\Delta^{12,13}$ \\
\hline 45 & H & Glc & H & $\mathrm{H}$ & $\Delta^{13,14}$ \\
\hline 46 & H & Glc & $\mathrm{H}$ & $\mathrm{H}$ & $\Delta^{11,12}, \Delta^{13,14}$ \\
\hline 47 & H & Glc & H & H & $\Delta^{13,14}$ \\
\hline 48 & H & $\mathrm{Glc}-6-\mathrm{Ac}$ & $\mathrm{H}$ & $\mathrm{H}$ & $\Delta^{13,14}$ \\
\hline
\end{tabular}<smiles>[X]CC=C(C)CC1(C)C(C)CCC2(C)C1CCCC2(C)C</smiles>

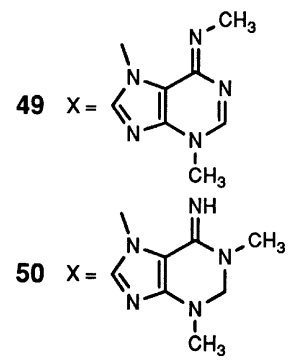

\section{Inhibitors of $\beta$-Glucuronidase}

From the roots of Scoparia dulcis (Scrophulariaceae) a plant used in folk medicine (21), a labdane diterpene scoparic acid (52) was isolated and found to inhibit the activity of $\beta$ glucuronidase isolated from bovine liver $\left(\mathrm{IC}_{50}=6.8 \times 10^{-6} \mathrm{M}\right)$.<smiles>C=C1CC(OCCOC)C2(C)C(C)CCC[C@]2(C)[C@@H]1CC/C(C)=C/CO</smiles>

\section{Inhibitors of Phospholipase $A_{2}$}

Halisulfate (17) isolated from the marine dark brown sponge (Halichondriidae), exhibiting antifungal and antibacterial activity (7) also showed $100 \%$ inhibition of the enzyme phospholipase $A_{2}$ at a concentration of $16 \mu \mathrm{g} / \mathrm{ml}$.

\section{Inhibitors of Superoxide Anion Radical Release}

From the fungus Cryptoporus volvatus (Polyporaceae) (22), the novel bitter dimeric drimane sesquiterpenoids, cryptoporic acid C (53) and E (54) were isolated which inhibited the release of superoxide anions from guinea pig peritoneal macrophages induced by the $\mathrm{O}_{2}{ }^{-}$stimulant FMLP (formyl-methionyl-leucylphenylalanine $10^{-7} \mathrm{M}$ ) with $\mathrm{IC}_{50}=0.07$ and $0.05 \mu \mathrm{g} / \mathrm{ml}$, respectively. Cryptoporic acid C (53) also inhibited the release of $\mathrm{O}_{2}{ }^{-}$ from rabbit polymerphonuclear leucocytes induced by the $\mathrm{O}_{2}{ }^{-}$ stimulant FMLP $\left(10^{-7} \mathrm{M}\right)$ with $\mathrm{IC}_{50}=2 \mu \mathrm{g} / \mathrm{ml}$.

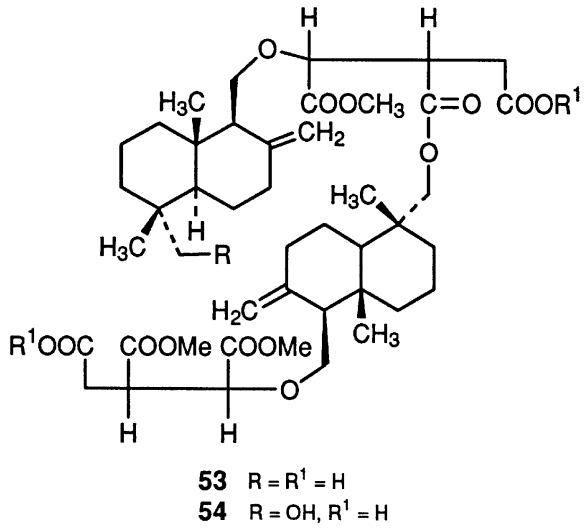

\section{Natural Sweetening Agents}

There are several sweetening agents available for people suffering from diabetes, for example, the sodium salt of saccharin. The plants that demonstrate hypoglycemic effects within the body play a major role in folk medicine. Stevioside and extracts prepared from the leaves of the plant Stevia rebaudiana have been used widely in Japan since the mid 1970s as sweetening agents, taste modifiers and sugar substitutes for patients with high initial blood sugar levels. 
In the continuing search for sweet compounds of plant origin, a chemical investigation was carried out on Baccharis gaudichaudiana (Compositae), a plant commonly known as "Chilca melosa" and used traditionally as an antidiabetic remedy (23). Leaves and stems of this plant exhibited a sweet taste accompanied by some bitterness. Among the five labdane type diterpene glycosides isolated, gaudichaudioside A (55) was found to be highly sweet and is the first member of a new class of intensely sweet substances. Before being assessed for sweetness, gaudichaudioside A (55) was found to be non-toxic in preliminary acute toxicity tests in mice and non-mutagenic towards Salmonella typhimurium strain TM 677 , both in the presence and absence of a metabolic activating system. Gaudichaudioside A (55) was found to exhibit about 55 times the sweetness potency of a $2 \% \mathrm{w} / \mathrm{v}$ aqueous sucrose solution. Gaudichaudiosides B-E (56-59) were found to be sweet bitter, neutral tasting, wholly bitter and sweet bitter, respectively, when tested as $0.5 \% \mathrm{w} / \mathrm{v}$ aqueous solutions. These compounds produced an initial sweet sensation lasting a few seconds which was then replaced by an entirely bitter taste.

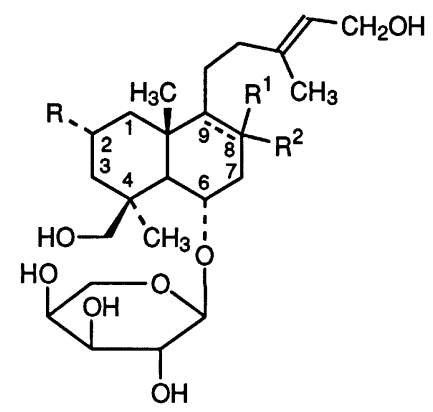

\begin{tabular}{l|llll}
\hline & $\mathbf{R}$ & $\mathrm{R}^{1}$ & $\mathrm{R}^{2}$ & \\
\hline $\mathbf{5 5}$ & $\mathrm{H}$ & $\mathrm{CHO}$ & $\mathrm{H}$ & $\Delta^{8,9}$ \\
$\mathbf{5 6}$ & $\mathrm{H}$ & $\mathrm{CH}_{2} \mathrm{OH}$ & $\mathrm{H}$ & $\Delta^{8,9}$ \\
$\mathbf{5 7}$ & $\mathrm{OH}$ & $\mathrm{CH}_{2} \mathrm{OH}$ & $\mathrm{H}$ & $\Delta^{8,9}$ \\
$\mathbf{5 8}$ & $\mathrm{H}$ & $\mathrm{\beta}^{-} \mathrm{CH}_{3}$ & $\alpha-\mathrm{OH}$ & \\
$\mathbf{5 9}$ & $\mathrm{OH}$ & $\mathrm{CH}_{3}$ & $\mathrm{H}$ & $\Delta^{8,9}$ \\
\hline
\end{tabular}

The genus Phlomis (Labiatae) consists of 100 species and the roots of P.younghusbandii and P. medicinalis are used as an antifebrile and as cough medicine in Tibet. From the roots of P. younghushbandii a known sweet furanolabdane type diterpenoid glucoside phlomisoside I (60) was isolated (24). There were two other new furanolabdane diterpenes isolated, named as phlomisoside III and IV, but these were tasteless. From the roots of P. medicinalis another sweet furanolabdane diterpenoid glycoside was isolated and identified as baiyunoside (61). Both the sweet diterpenoids were isolated earlier $(25,26)$ from the roots of a Chinese plant Salvia digitaloides known under the name of crude drug "Bai-Yun-Shen". Looking closely at the structure of sweet furanolabdane diterpenoid glycoside and the tasteless furanolabdane diterpenoid glycoside, the structure-taste relationship could be deduced and the conclusion drawn from the above observation is that the presence of the $3-\mathrm{OH}$ group to which the sugar moiety is attached is essential and that a gem-dimethyl at C-4 is also essential.<smiles>[R]C1=C(C)C([R])C2(C)CCC(P)C(C)(C)C2C1P</smiles>

(1)

The total syntheses of naturally occurring sweetening agents and their analogs have been carried out. The aglycone of these furanolabdane diterpenoid glycosides is (+)-baiyunol. Total synthesis of $( \pm)$-baiyunol and chiral synthesis of $(+)$-baiyunol were carried out with (S)-3-hydroxy-2,2-dimethylcyclohexanone as the starting material (27). In continuation of this work, the total synthesis of baiyunoside (61) was carried out from ( \pm )-baiyunol (28) utilizing a novel 2'-discriminated glycosidation reaction. The synthetic baiyunoside (61) was found to be very sweet and this opened a new area to develop high quality artificial sweetners.

Later on, baiyunoside (61) and the related glycosides phlomisosides I and II as well as 23 different analogs with different glycosidic linkages were synthesized (29). Artificial phlomisosides I and II were synthesized with glucose-rhamnose and glucose-glucose linkages. Taste analysis of each synthetic glycoside was done using a $0.1 \%$ aqueous solution and compared with the taste of baiyunoside (61). Among the glucose-xyloses of (-)-baiyunol derivatives, $\beta$-glucose- $\beta$-xylose derivatives showed a moderate sweet taste. Among the four rhamnose derivatives, phlomisoside I $(\mathbf{6 0})$ showed a strong sweet taste, as sweet as baiyunoside (61), whereas the remaining three stereoisomers were tasteless. Phlomisoside II, $( \pm)$-baiyunol with $\beta$-glucose- $\beta$-glucose, showed a strong bitter taste whereas the $\beta$-glucose- $\alpha$-glucose derivatives showed a very strong sweet taste. (+)-Baiyunol with $\alpha$ glucose- $\beta$-glucose was moderately sweet whereas the $\alpha$ glucose- $\alpha$-glucose was tasteless. Synthetic baiyunoside was as sweet as natural baiyunoside.

\section{Conclusions}

The variety of biological activities encountered in labdane diterpenes indicates that the plants still hold the key to new drug discovery. Synthesis of the decaline system which is the basic unit of all the labdane diterpenes is a commercially viable proposition. Therefore the preparation of new analogues of this skeletal type could be carried out to get new leads in drug development.

\section{References}

${ }^{1}$ Chinou, I., Demetzos, C., Harvala, C., Roussakis, C., Verbist, J. F. (1994) Planta Med. 60, 34-36.

2 Iwagawa, T., Yaguchi, S., Hase, T., Okubo, T., Kim, M. (1992) Phytochemistry 31,1311-1315. 
3 Iwagawa, T., Yaguchi, S., Hase, T., Okubo, T., Kim, M. (1993) Phytochemistry 32,1515-1518.

${ }^{4}$ Muhammad, I., Mossa, J. S., Feraly, F. S. El. (1996) Phytother. Res. $10,604-607$.

${ }^{5}$ Habtemarian, S., Gray, A. I., Waterman, P. G. (1992) Planta Med. $58,109-110$.

6 Tanaka, J., Higa, T., Suwanborirux, K., Kokpol, U., Bernardinelli, G., Jefford, C. W. (1993) J. Org. Chem. 58, 2999-3002.

7 Kernan, M. R., Faulkner, D. J. (1988) J. Org. Chem. 53, 4574- 4578.

8 Mortia, H., Itokawa, H. (1988) Planta Med. 117-120.

${ }^{9}$ Herlem, D., Kervagorel, J., Khuong-Huu, F. (1989) Tetrahedron Lett. 30, 553-556.

${ }^{10}$ Kimbu, S. F., Ngadjui, B., Sondengam, L. B. (1987) J. Nat. Prod. 50, 230-231.

11 Banthorpe, D. V., Brown, J. T., Morris, G. S. (1990) Phytochemistry 29, 2145-2148.

12 Shimizu, M., Tsuji, H., Shogawa, H., Fukumura, H., Tanaami, S., Hayashi, T., Arisawa, M., Morita, N. (1988) Chem. Pharm. Bull. 36, $3967-3963$.

13 Richomme, P., Godet, M. C., Foussard, F., Toupet, L., Sevenet, T., Bruneton, J. (1991) Planta Med. 57, 552 - 554.

14 Sethi, A., Khare, A., Khare, M. P. (1988) Phytochemistry 27, 2255 2259.

15 Itokawa, H., Morita, H., Katou, I., Takeya, K., Cavalheiro, A. J., Oliveir, R. C. B., Ishige, M., Motidome, M. (1988) Planta Med. 311 315.

${ }^{16}$ Demetzos, C., Mitaku, S., Couladis, M., Harvala, C., Kokkinopoulos, D. (1994) Planta Med. 60, 590-591.

17 Matsuda, T., Kuroyanagi, M., Sugiyama, S., Umehara, K., Ueno, A., Nishi, K. (1994) Chem. Pharm. Bull. 42, 1216-1225.

18 Afshar, R. F., Allen, T. M. (1988) Can. J. Chem. 66, 45-50.

19 Nakagawa, M., Ishihama, M., Hamamoto, Y., Endo, M. (1986) Abstract of Paper of 28th Symposium on the Chemistry of Natural Product, Japan, p. 200; C.A. 106, 96126b (1987).

${ }^{20}$ Hagiwara, H., Uda, H. (1988) J. Chem. Soc., Chem. Commun. 815817.

${ }^{21}$ Kawasaki, M., Hayashi, T., Arisawa, M., Shimizu, M., Horie, S., Ueno, H., Syogawa, H., Suzuki, S., Yoshizaki, M., Morita, N., Tezuka, Y., Kikuchi, T., Berganza, L. H., Ferro, E., Basuaido, I. (1987) Chem. Pharm. Bull. 35, 3963 - 3966.

22 Hashimoto, T., Tori, M., Mizuno, Y., Asakawa, Y., Fukazawa, Y. (1989) J. Chem. Soc. Chem. Commun. 258 - 259.

23 Fullas, F., Hussain, R. A., Bordas, E., Pezzuto, J. M., Soejarto, D. D., Kinghorn, A. D. (1991) Tetrahedron 47, 8515-8522.

24 Katagiri, M., Othani, K., Kasai, R., Yamasaki, K., Yang, C. R., Tanaka, O. (1994) Phytochemistry 35, 439-442.

25 Tanaka, T., Tanaka, O., Lin, Z. W., Zhou, J. (1985) Chem. Pharm. Bull. 33, 4275.

26 Tanaka, T., Tanaka, O., Lin, Z. W., Zhou, J., Ageta, H. (1983) Chem. Pharm. Bull. 31, 780.

27 Mori, K., Komatsu, M. (1987) Tetrahedron 43, 3409-3412.

28 Yamada, H., Nishizawa, M. (1987) Tetrahedron Lett. 28, 43154318.

29 Yamada, H., Nishizawa, M. (1992) Tetrahedron 48, 3021 - 3044.

\section{R. P. Sharma}

Phytochemical Technology Division Central Institute of Medicine and Aromatic Plants CIMAP

Lucknow 226015

India

E-mail: root@cimap.sirnetd.ernet.in

Fax: +91(0)522342666 